\title{
Mycobacterium tuberculosis ANTIGENS MPT63 AND MPT83 INCREASE PHAGOCYTIC ACTIVITY OF MURINE PERITONEAL MACROPHAGES
}

\author{
A. A. SIROMOLOT ${ }^{1,2}$, O. S. OLIINYK', D. V. KOLIBO ${ }^{2,1}$, S. V. KOMISARENKO \\ ${ }^{1}$ Educational and Scientific Centre Institute of Biology, \\ Taras Shevchenko National University of Kyiv, Ukraine; \\ ${ }^{2}$ Palladin Institute of Biochemistry, National Academy of Sciences of Ukraine, Kyiv; \\ e-mail:saa0205@ukr.net
}

\begin{abstract}
Macrophages $(M \Phi)$ are the most described and characterized target and host of mycobacteria. Like

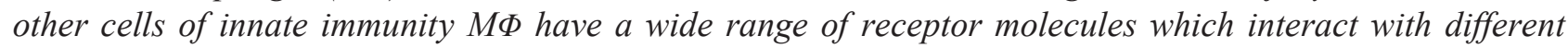
pathogen associated molecular patterns (PAMPS). Immunodominant proteins MPT63 and MPT83 that are synthesized in abundance by Mycobacterium bovis or Mycobacterium tuberculosis strains could be involved in development of tuberculosis infection. The aim of this study was to search for effects of these mycobacterial antigens on target cells. For this aim full-sized sequences of MPT83 (rMPT83full) and MPT63 antigens were cloned into plasmid pET24a(+). The increase of phagocytic activity of murine peritoneal macrophages was demonstrated, but not of macrophage-like cells from J774 cell line, which were treated by rMPT63 and rMPT$83 f u l l$ proteins for $24 \mathrm{~h}$. This effect of such antigens can be considered as a way to facilitate the consumption of mycobacterial cells by macrophages to avoid other effector mechanisms of innate and adaptive immunity.
\end{abstract}

Key words: Mycobacterium tuberculosis, Mycobacterium bovis, macrophages, phagocytosis, MPT63, MPT83.

$\mathrm{K}$ nowledge about mechanisms of pathogenesis and development of tuberculosis (TB) is rapidly growing. The arising of multidrugresistant strains of Mycobacterium (MDR-TB) promotes finding new effective therapeutic agents. Interactions of bacterial pathogenic factors with target molecules lead to particular effects in host. Thus, the investigation of features and functions of a number of tuberculosis bacilli antigens is a prerequisite for prevention and treatment of TB.

The genome of Mycobacterium contains consists of about 3989 genes that encode functional products, only $30 \%$ of them performing the known functions and $70 \%$ being classified as hypothetical [1]. Identification of cellular and molecular targets for immunodominant proteins MPT63 and MPT83 could fill certain gaps in understanding the mechanism of tuberculosis pathogenesis. Also, it remains unclear whether some $M$. tuberculosis antigens, including MPT63 and MPT83, are involved in avoiding bacteria degradation in endosomes. Therefore, the study of the role of $M$. tuberculosis proteins with unknown functions in the development of infection in susceptible hosts is one of the priority tasks.
The innate immune system, including $\mathrm{M} \Phi$, is the main chain of all immune networks, which is responsible for elimination and deactivation of numerous pathogens. However, inner environment of $M \Phi$ is a favorable place for reproduction and survival of M. tuberculosis [2]. Apparently, active phagocytosis of different bacilli by $\mathrm{M} \Phi$ leads to pathogen lysis and future patient recovery. However, pathogenic mycobacterial strains survive inside macrophages by arresting the normal maturation of their phagosome and limiting fusion with pre-formed lysosomes [3]. Obviously, the components of bacteria cell wall and some proteins products are involved in these processes.

MPT63 is $16 \mathrm{kDa}$ secreted protein that had relatively high expression level in mycobacteria. Firstly this antigen was obtained from $M$. tuberculosis culture fluid in 1991 by Nagai and colleagues [4]. Analysis of the nucleotide sequence of mpt63 identified open reading frame, and it was shown that the protein consists of 159 amino acids and contains two components: a signal peptide that has 29 amino acids and entire MPT63, which contains 130 amino acids [5]. The orthologs MPB63 from M. bovis and 
MPT63 from M. tuberculosis have difference of one nucleotide in their gene sequences but are not distinguished in functional products. The recombinant MPT63 isolated from Escherichia coli and natural protein of M. tuberculosis MPT63 did not differ by the results of serological tests $[6,7]$.

Moreover, homologs of MPT63 have been found in different strains, but polyclonal antibodies against MPT63 from M. tuberculosis do not crossreact with them $[8,9]$. Some mycobacterial species have mpt63 gene which are not translated into protein product [8]. Therefore, rMPT63 is a valuable target for immunological studies.

Though the function of MPT63 remains unknown, there have been few studies of MPT63 effect on in vitro systems. However there is little information available about targets of MPT63 on cells and activation cascades associated with them. As a rule, bacteria proteins have effect on cytokine production, such as tumor necrosis factor alpha (TNF- $\alpha$ ) and interleukin 6 (IL-6). Degranulation and release of histamine and hexaminidase from mast cells caused by MPT63 is demonstrated [10]. Surprisingly, that other M. tuberculosis antigens ESAT-6 and MTSA10 showed a similar result.

Another important immunodominant antigen of M. tuberculosis is a membrane binding lipoprotein MPT83 [11]. This molecule is one of the ligands for toll-like receptor 2 (TLR-2) and could bind with human TLR-2 with affinity about $4.42 \times 10^{-8} \mathrm{M}$ [12]. Also M. tuberculosis has a number of molecules that bind and activate TLR-2 (lipoproteins LpqH, LprG, LprA and PhoS1, lipoarabinomanan, lipomanan and phosphatidylinositol mannoside (PIM). Prolonged stimulation of macrophages with these ligands leads to the production of immunosuppressive cytokines (including IL-10 and IL-4) and reduction of major histocompatibility complex (MHC) class II expression and inhibition of antigen processing [13]. Probably, TLR-2 is not the only possible target for MPT83. Thus, MPT83 stimulation of M $\Phi$ from TLR-2 knockout mice resulted in a significant increase of TNF- $\alpha$, IL-6 and IL-12 synthesis, although lower than for wild-type mice macrophages [14]. Similarly, the blocking of TLR-2 with antibodies reduces but not abolishes MPT83 effects [12].

Chambers and colleagues [12] offered that glycosylated and acetylated protein could take influence on matrix metalloproteinase (MMP) expression through interaction with TLR-2, TLR-1 or TLR-4. Nevertheless, it was shown that recombinant protein (not glycosylated and not acetylated) could activate the production of metalloproteinases too. The above evidence provides the value and adequacy for using the recombinant proteins MPT63 and MPT83 in investigation of their functions.

According to the literature macrophages and macrophage-like cells are the main target of mycobacteria, but for many Mycobacterium antigens the functions have not been found yet. Our goal was to show some effects of $M$. tuberculosis/M. bovis antigens MPT63 and MPT83 on selected cells models.

We have chosen two models to achieve the objective, primary culture of macrophages from peritoneal cavity of mice and macrophage-like cells of $\mathrm{J} 774$ cell line source which is also murine. Effects could differ after treatment of primary culture and malignant cells by antigens. The absence of registered changes in phagocytosis assay in J774 cell line has focused our investigation on peritoneal macrophages only.

We previously cloned MPT63 and fragment of MPT83 that corresponded to sequence 115-220 aa of fasciclin-like domain (FLD) (94-217 aa) [6]. In the current study we focused on the effects of rMPT63 and rMPT83full on macrophages phagocytosis activity. Our results have shown that both rMPT63 and rMPT 83 increase percentage of macrophages that actively consume EGFP expressed E. coli. Moreover, such influence of recombinant antigens did not depend on E. coli expression system, because control proteins, which were expressed and obtained from similar expression system, had no effect on phagocytosis.

\section{Materials and Methods}

Mice and cells. BALB/c female white mice (30$35 \mathrm{~g}$ of body mass) were used in the experiments. Mice were kept in cages of research vivarium, fed a standard diet and had free access to water. The animals $(n=12)$ were used for obtaining peritoneal macrophages.

The experiments are consistent with the requirements of the European Convention for the Protection of Vertebrate Animals used for Experimental and Other Scientific Purposes (Strasbourg, 1986) and with ethical norms as laid down in the laws of Ukraine.

Sterile saline was injected in the plot of peritoneal cavity. Belly was massaged gently for $M \Phi$ washed per $1 \mathrm{~min}$. A small patch of skin was cut by scissors without damage of the peritoneal cavity in- 
tegrity. Using a syringe carefully selected fluid with cells and transferred it to clean dishes. The liquid was centrifuged during $5 \mathrm{~min}$ at $300 \mathrm{~g}$, the supernatant was collected and cells were washed twice in phosphate buffered saline (PBS). Cells' precipitate was resuspended in RPMI-1640 medium with L-glutamine, $50 \mathrm{mg} / \mathrm{l}$ cefalotin and with addition fetal bovine serum (FBS) to final concentration of $10 \%$ and transferred to a new dish. Peritoneal $\mathrm{M} \Phi$ and macrophage-like cells of J774 cell line were cultivated in cell culture flasks and maintained at $37{ }^{\circ} \mathrm{C}$ in a humidified incubator in $5 \% \mathrm{CO}_{2}$ atmosphere. After $\mathrm{M} \Phi$ adhesion to the bottom of the dish there are twice washed by PBS from on the medium, serum and red blood cells. Cells were removed by $30 \mathrm{mM}$ EDTA solution in PBS for $15 \mathrm{~min}$ at $37^{\circ} \mathrm{C}$ and active mixing.

Cloning of MPT83full in Escherichia coli. Fragment of mpt83(full) gene was amplified by PCR from vaccine strain $M$. bovis BCG-Russia by 2 oligonucleotides: MPT83 L SP 5'-TGGATCCAGCACCAAACCCGTGTCGCA-3' and MPT83 L ASP 5'-AATCTCGAGCTGTGCCGGGGGCATCAG-

CA-3'. PCR amplification was performed under the following conditions: incubation at $94^{\circ} \mathrm{C}$ for $3 \mathrm{~min}$; 28 cycles at $94{ }^{\circ} \mathrm{C}$ for $30 \mathrm{~s}$, at $55^{\circ} \mathrm{C}$ for $30 \mathrm{~s}$ and at $72{ }^{\circ} \mathrm{C}$ for $1 \mathrm{~min}$; and extension at $72{ }^{\circ} \mathrm{C}$ for $7 \mathrm{~min}$. PCR products were extracted and purified using GeneJet Gel Extraction Kit. Plasmid DNA was obtained by GeneJet Plasmid Miniprep Kit. All manipulations were performed according to the manufacturer's manual recommendations. The amplified $m p t 83$ (full) gene was ligated with the $E$. coli expression vector $\mathrm{pET} 24 \mathrm{a}(+)$ (Novagen, Germany) using $B a m \mathrm{HI}$ and $\mathrm{XhoI}$ restriction sites. The obtained construct was used to transform E. coli Rosetta (DE3) host cells (Novagen, Germany) for protein expression. Several clones verified with PCR were frozen.

Immobilized-metal affinity on-column chromatography of His-tag proteins. MPT63 and MPT83full expressed $E$. coli cells were grown in LB medium with $50 \mu \mathrm{g} / \mathrm{ml}$ kanamycin and $1 \%$ glucose at $37^{\circ} \mathrm{C}$ and active mixing (250 rpm) to optical density $\mathrm{A}_{600}$ 0.3-0.5. The expression of mycobacterial proteins was induced by $1 \mathrm{mM}$ isopropyl- $\beta-\mathrm{D}$ thiogalactopyranoside (IPTG). Cell precipitates of MPT63 expressed E. coli were resuspended in wash buffer (50 mM Na${ }_{2} \mathrm{HPO}_{4},(\mathrm{pH} \mathrm{8.0)}, 0.5 \mathrm{M} \mathrm{NaCl})$, which contains $6 \mathrm{M}$ urea and treated on ice with ultrasonic disintegrator Labsonic (Sartorius, Germany) and centrifuged during $20 \mathrm{~min}$ at 13,000 rpm.
The supernatant was applied to a pre-equilibrated Ni-NTA agarose (Qiagen, Germany) column and washed with $6 \mathrm{M}$ urea buffer. Elution of purified proteins was conducted in buffer with $250 \mathrm{mM}$ imidazole and $6 \mathrm{M}$ urea. After purification recombinant protein was dialyzed in PBS $(0.8 \% \mathrm{NaCl}, 0.02 \%$ $\mathrm{KCl}, 0.144 \% \mathrm{Na}_{2} \mathrm{HPO}_{4}, 0.024 \% \mathrm{KH}_{2} \mathrm{PO}_{4}, \mathrm{pH} 7.4$ ).

MPT83full expressed E. coli cells were resuspended in PBS and were treated and centrifuged as described above. MPT83full protein extraction was carried out in non-denaturating conditions using wash buffer without urea reagent.

SDS-PAGE and Western blotting. Protein molecules were separated by $10 \%$ SDS-PAAG electrophoresis under denaturating condition in Tris-tricine buffer system. We used a buffer sample that contained $\beta$-mercaptoethanol for prevention of dimers formation and buffer without disulfide reduction components. Staining was performed using Coomassie Brilliant Blue G-250. Protein concentration was determined by densitometry using special computer program TotalLab TL120.

Protein transfer to nitrocellulose membrane was performed using semi-dry Western blot during $2 \mathrm{~h}$ and current strength $38 \mathrm{~mA}$ in the buffer which contained $25 \mathrm{mM}$ Tris- $\mathrm{HCl}, \mathrm{pH} 8.3,20 \%$ methanol, $192 \mathrm{mM}$ glycine.

After transferring the membrane was blocked by $5 \%$ non-fat milk dissolved in PBS during $1 \mathrm{~h}$ at $37^{\circ} \mathrm{C}$. Then the membrane was washed three times by T-PBS $\left(0.8 \% \mathrm{NaCl}, 0.02 \% \mathrm{KCl}, 0.144 \% \mathrm{Na}_{2} \mathrm{HPO}_{4}\right.$, $0.024 \% \mathrm{KH}_{2} \mathrm{PO}_{4}, 0.04 \%$ Tween-20, $\mathrm{pH} 7.4$ ) and incubated with anti-His tag antibodies (1:3000) conjugated with horseradish peroxidase. Bands have been detected by 3,3'-Diaminobenzidine tetrahydrochloride (DAB) chromogenic substrate.

Flow cytometry and Phagocytosis assay. Peritoneal $\mathrm{M} \Phi$ and macrophage-like cells from $\mathrm{J} 774$ cell line incubated in cell culture flasks $\left(1 \times 10^{6} \mathrm{cells} / \mathrm{dish}\right)$ with rMPT63, rMPT83 and mCherry $\left(0.25 \times 10^{-6} \mathrm{mM}\right)$ as a control for $0.5,1,2$ and $24 \mathrm{~h}$. After cultivation the macrophages were incubated with EGFP expressed E. coli cells during $30 \mathrm{~min}$ at $37{ }^{\circ} \mathrm{C}$ in the ratio of 100 bacterial cells per one macrophage. Cells were washed from not phagocytized bacteria and in PBS-BSA $(0.8 \% \mathrm{NaCl}, 0.02 \% \mathrm{KCl}, 0.144 \%$ $\mathrm{Na}_{2} \mathrm{HPO}_{4}, 0.024 \% \mathrm{KH}_{2} \mathrm{PO}_{4}, \mathrm{pH} 7.4,2 \%$ BSA). Samples were analyzed by flow cytometry (Beckman Coulter Epics XL) using FL1 channel laser and calibrator with 50000 total events/sample. 
The temperature, lack of sodium azide meet conditions for active uptake of EGFP expressed Escherichia by macrophages. Bacteria with the accumulated protein fluoresces actively even after the takeover by macrophages. Green laser channel was identified increase in fluorescence, which means an increase of phagocytized bacteria by a permanent amount of macrophages.

\section{Results and Discussion}

Vector construction for rMPT83full expression. Full mpt83 gene was amplified by PCR (Fig. 1, $A)$ and cloned into vector for protein expression pET24a $(+)$ (Novagen, Germany) by restriction sites BamHI and XhoI (Fig. 1, B). The number of copies of pET24a-mpt83(full) vector were amplified in E. coli DH10B strain. The mpt63 gene was cloned into pET24 vector previously [6].

E. coli Rosetta DE3 strain cells were transformed by pET24a-mpt83. Cells were grown on solid culture medium LB at $37{ }^{\circ} \mathrm{C}$ with addition of selective antibiotic kanamycin. Selected clones were tested for the presence of the correct inserted gene fragment by PCR (Fig. 1, C). The expected amplified fragment length was approximately 900 b.p.
Expressed recombinant proteins obtaining and purification. Selected clones of MPT83full and MPT63 expressed E. coli were induced with $1 \mathrm{mM}$ IPTG and incubated for $4 \mathrm{~h}$ at $30^{\circ} \mathrm{C}$ with intensive aeration. His-tag labeled proteins were isolated by IMAC on Ni-NTA agarose (Qiagen, the Netherlands). Elution was performed by competitive displacement of protein molecules with $250 \mathrm{mM}$ imidazole solution in wash buffer under denaturing (MPT63) and non-denaturing (MPT83full) conditions. Final fractions had been analyzed by $10 \%$ SDS-PAGE (Fig. 2, A). Also, the electrophoretic mobility of the rMPT83full protein depends on the presence or absence of disulfide reduction component in sample buffer (Fig. 2, B).

The cloning of the full length rMPT83 mycobacterial protein was needed to study the effect of all sequence of the antigen, but not only FLD rMPT83(115-220) [6], on M $\Phi$. Despite the lower yield of protein from 1 liter of $E$. coli culture, fullsize MPT83 was identified in the soluble cytoplasmic fraction that gives it in correctly folded conformation. In contrast, FLD rMPT83 (115-220) was identified in insoluble inclusion bodies (Fig. 2, A). Furthermore, full-size MPT83 does not form dimers,

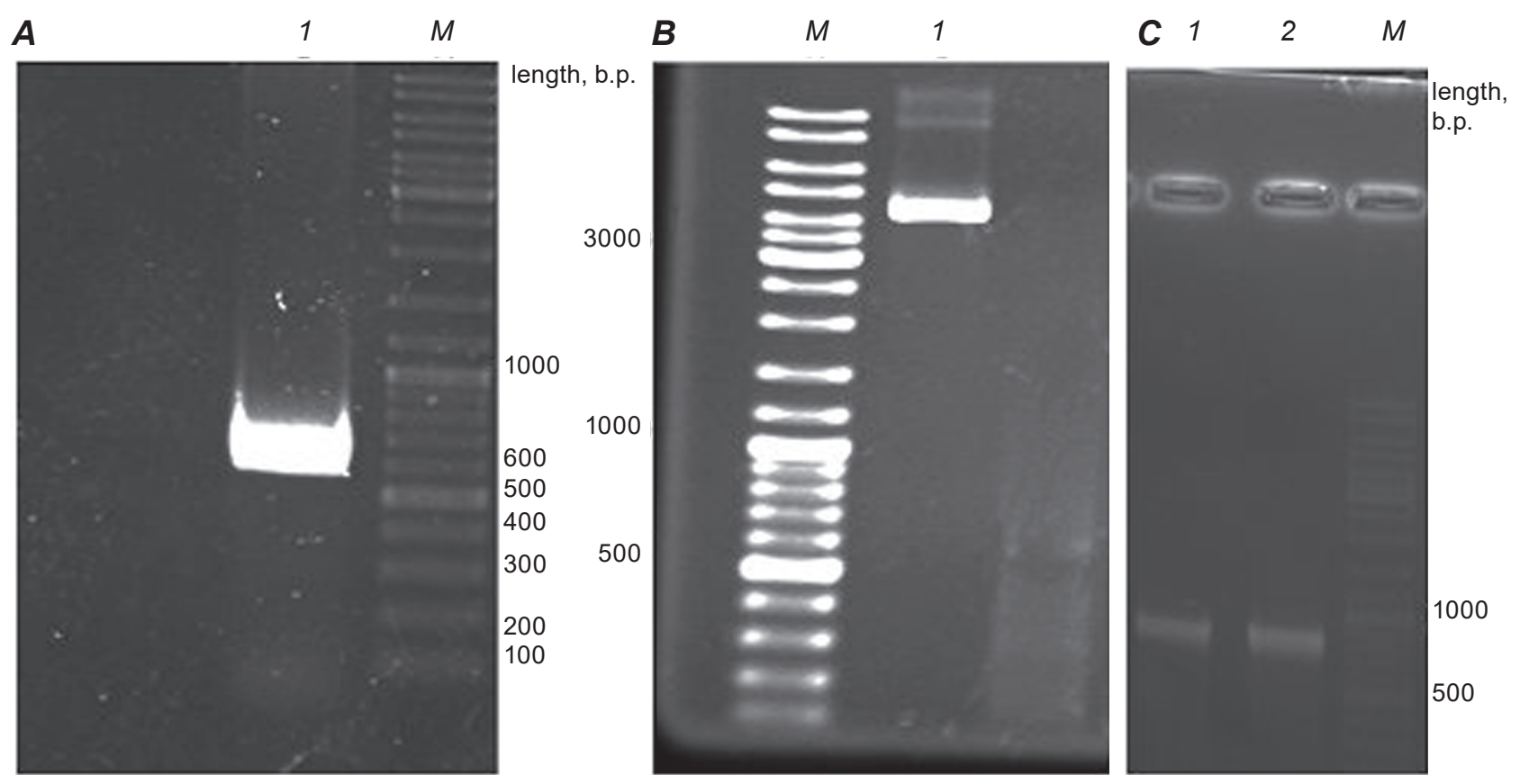

Fig. 1. Construction of pET24a-mpt83(full) vector for protein expression. A-the mpt83(full) gene amplified by PCR from M. bovis-BCG Russia. B - construct of mpt83(full) gene sequence cloning into $p E T 24 a(+)$ vector by restriction sites BamHI and XhoI. C-correct gene insert from E. coli transformed cell colonies was verified by PCR within pair pET-oligos 
A

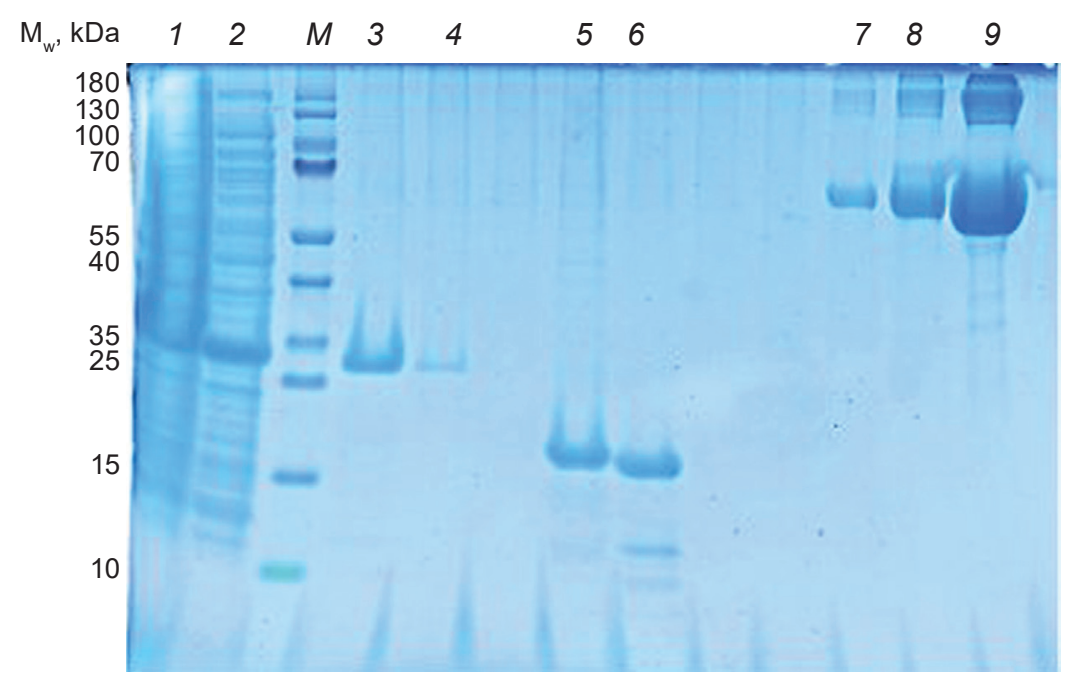

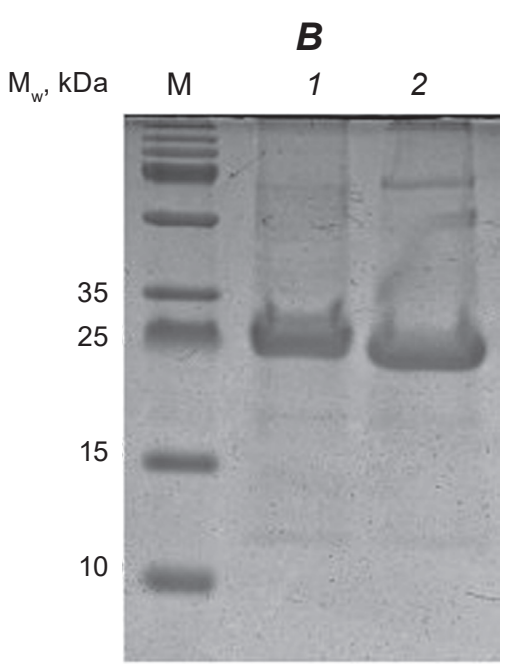

Fig. 2. Electrophoresis assay of novel obtained protein MPT83full. A-lane 1 and 2 -insoluble and soluble fractions of E. coli cell lysates, which contain non-purified MPT83full. Lane 3, 4-MPT83full purified on Ni-NTA agarose under denaturing conditions. Lane 5, 6-FLD rMPT83 obtained and purified under denaturing conditions. Samples 7, 8, $9-B S A$ for protein concentration calibration. B-electrophoretic mobility of MPT83full within the sample buffer without (lane 1) and with (lane 2) disulfide bonds reduction reagent DTT. Different mobility of MPT83full provides existence of the inner disulfide bond

unlike its short analog (Fig. 2, B; Fig. 4). This also proves the value feasibility of using the product of a full gene sequence in which the N'-terminal amino acids play a potentially important role in protein folding. Therefore, the action of FLD rMPT83 (115220) on phagocytosis assay was not studied.

Primary culture but not malignant macrophages have higher phagocytic activity after $24 \mathrm{~h}$ rMPT63 and rMPT83full stimulation. For phagocytosis test we used a transformed green fluorescent protein E. coli, according to the protocol described in Gille et al [15]. Protocol has been tested on J774 cells. Phagocytosis level was estimated by flow cytometry in order to obtain data for the large number of cells.

After rMPT63 and rMPT83full stimulation the number of phagocytic peritoneal $\mathrm{M} \Phi$ was increased. However, any significant differences in phagocytosis level for incubation period of $30 \mathrm{~min}$, 1 or $2 \mathrm{~h}$ was not found. However after $24 \mathrm{~h}$ rMPT63 and rMPT83full stimulation of peritoneal $M \Phi$ the number of phagocytic cells was increased twice. The control proteins did not lead to such effect and the number of phagocytic cells was at the level of unstimulated cells (Fig. 3, $A, B$ ).

Unlike peritoneal murine $\mathrm{M} \Phi$ the malignant macrophage-like cells from $\mathrm{J} 774$ cell line were not characterized by any increase in phagocytosis, even after $24 \mathrm{~h}$ of stimulation.

The goal of our study was to investigate by flow cytometry the quantitative parameters of phagocytosis of EGFP expressed E. coli cells by mouse $\mathrm{M} \Phi$ under application of mycobacterium proteins to them. Flow cytometry allows analyzing a larger sample of cells compared with the conventional microscopic analysis [16, 17]. Furthermore, the method allows an objective quantitation of the phagocytic activity to give two parameters, such as phagocytic rate and index. The present results show that the phagocytic activity of cultured mouse peritoneal $M \Phi$ increased after the exposure to rMPT63 or rMPT83full. While preincubation of the cells with mCherry or EGFP showed a negligible change in the amount of actively phagocytic $\mathrm{M} \Phi$, we concluded that the effect of rMPT63 and rMPT83full was specific.

There are two potential ways to increase activity of phagocyte link of innate immunity of the host. First of them is the increase of the number of phagocytic cells which intake the same number of particles (e.g. EGFP expressed E. coli). Another way implies intensification of phagocytosis activity of each individual cell, which is belonging by constant rate to cell population. However, intensification of 


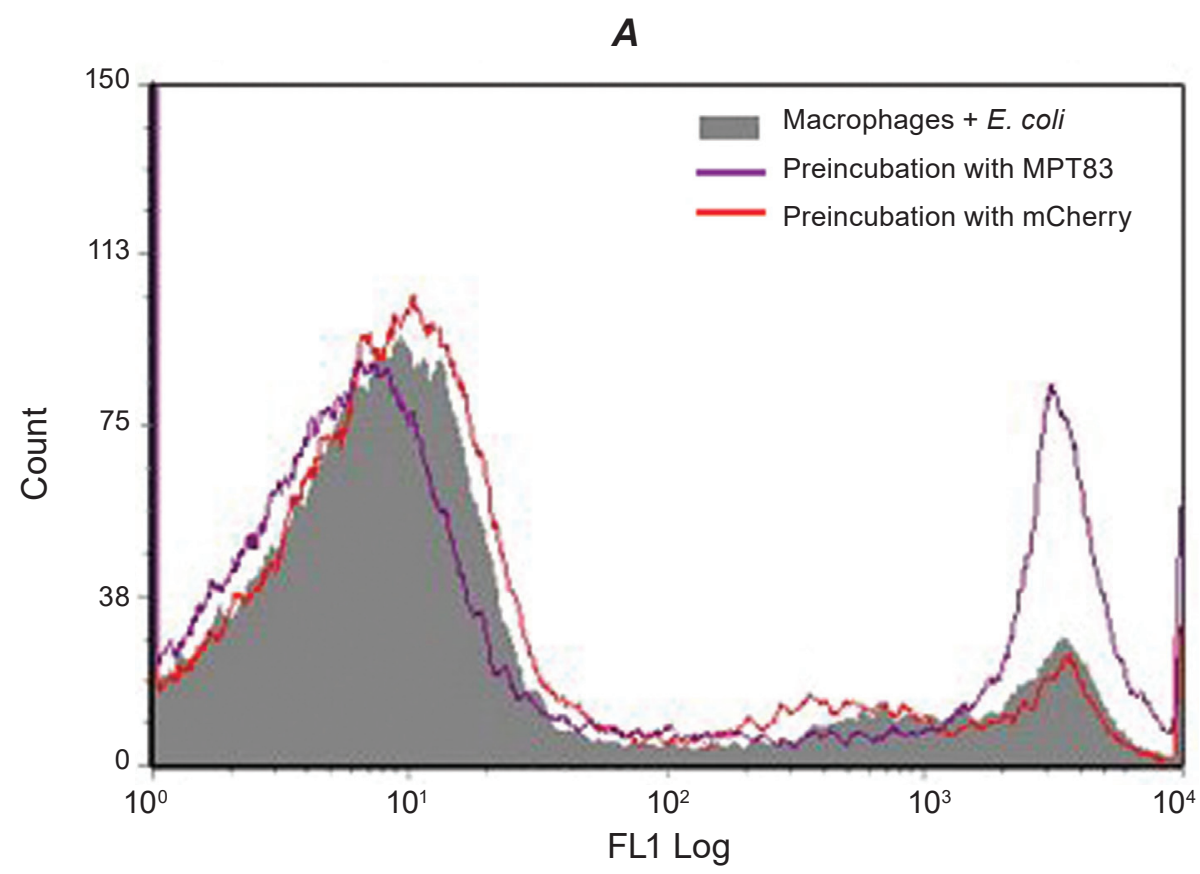

B

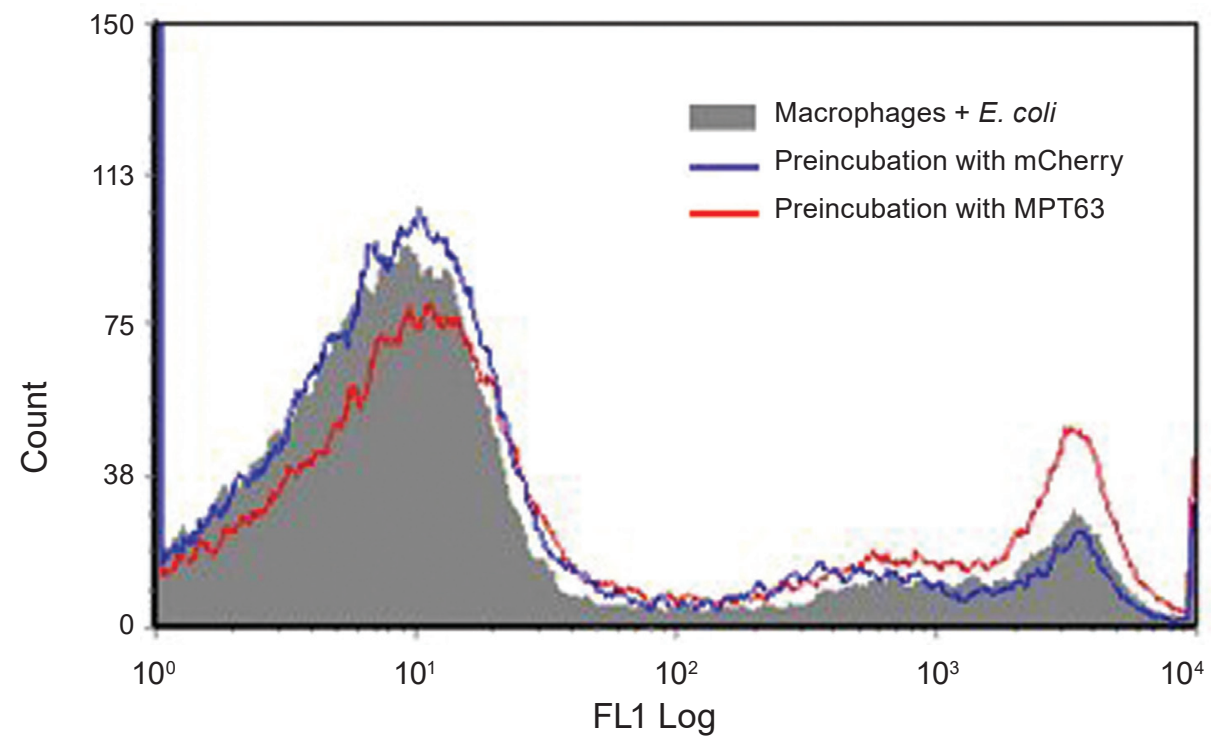

Fig. 3. Recombinant MPT63 and MPT83full induce active intake of EGFP expressed E. coli by peritoneal macrophages after 24 h preincubation. The level of bright luminous macrophages after EGFP expressed E. coli capture was observed by flow cytometry after exposure to MPT63 and MPT83 compared to control antigen. The percentage of actively phagocytic cells was increased 2 times for both mycobacterial antigens $(A, B)$ compared with unstimulated macrophages and stimulated by mCherry

phagocytosis also may occur by both mechanisms simultaneously.

Using flow cytometry we have shown not only the increase of the intensity, but also of the number of phagocytic cells, which grew twofold in both cases under the action of studied mycobacterial proteins. The percentage of stained cells increased to $19.1 \%$ after MPT63 treatment in comparison with $10.5 \%$ of intact (without treatment) cells and $10.9 \%$ which were in preincubation with mCherry and to $19.8 \%$ after MPT83full stimulation in comparison with $10.5 \%$ of intact cells and $10.9 \%$ which were pre-incubated with mCherry (Fig. 3). Furthermore, this effect was caused by long-term stimulation of 


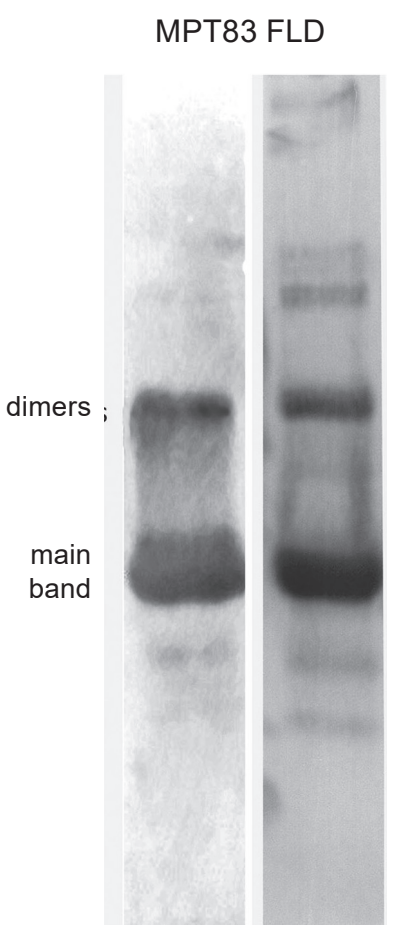

Fig. 4. Dimers of FLD rMPT83 identified by Western blot with anti-HisTag-HRP conjugate

cells. Treatment of mouse $\mathrm{M} \Phi$ for $0.5,1$ and $2 \mathrm{~h}$ had no effect on the increase of phagocytic activity compared with control samples. This effect was caused only after $24 \mathrm{~h}$ of incubation, which was probably related to changes in gene expression than to release from the inner cell store molecules which had been involved in phagocytosis.

The fact that malignant mouse macrophagelike cells from $\mathrm{J} 774$ cell line did not respond to the effect of mycobacterium proteins observed in primary cultures of $M \Phi$ is to be discussed. Some malignant cell lines have excessive activation, including phagocytic activity rate [18]. Therefore, we cannot detect changes in phagocytic activity of these cells under stimulation with mycobacterial proteins. Also we suppose that molecular targets of the investigated proteins on the cell surface may be expressed on discrete population at the distinct stage of differentiation, which is better represented in primary culture.

The control antigens, like EGFP and mCherry, which were used in the phagocytosis assay, as well as rMPT63 and rMPT83full, were cloned in identical prokaryotic expression system and obtained and purified under the same conditions. So, we can exclude the effect of contamination and hence the effect caused by the bacterial wall components, like other features of products from recombinant origin.

For many infection diseases $M \Phi$ provide the last niches for pathogen degradation and elimination, whereas mycobacteria can evade and coexist with these cells of host organism. Tuberculosis bacilli affect $\mathrm{M} \Phi$ and persist in these cells avoiding endosome-lysosome fusion [3]. As a result, vesicles do not become acidic and bacteria survive.

The authors proposed that $\mathrm{M} \Phi$ were the first target of MPT63 and MPT83 proteins of mycobacteria and theirs receptor molecules are localized at the surface of these cells. Also, we suggest that these immunodominant mycobacterial proteins facilitate bacteria cell phagocytosis for their survival inside $M \Phi$. This can represent one of the ways how bacteria could escape from the environment outside the cell in the organism, which has many factors of innate and adaptive immunity that can eliminate pathogen.

As a consequence of phagocytosis mycobacteria are able to grow and reproduce within phagocyte. Perhaps, one of the many actions of MPT63 and MPT83 could be directed precisely to such "specific" protecting of the pathogen from the host immune system. Of course, this is only the first evidence, and further study of these antigens is required.

Thus, obtained previously MPT63 and for the first time cloned and obtained MPT83full strengthen phagocytic function of immune system cells. The value of full-size antigen in comparison with its short fragment FLD rMPT83(115-220) obtained previously in our lab shows its identification in the soluble fraction, which indicates the correct folding of molecules in spite of a lower yield of new protein. The ability to induce phagocytosis by products of contamination of prokaryotic expression system (e.g. lipopolysaccharide (LPS), teichoic acids) were offset by no increase of phagocytosis after control proteins treatment despite the same plasmid DNA, where their genes were inserted and obtained and purified by the same methods as for MPT63 and MPT83. The investigated effect caused by the chosen mycobacterial antigens was observed in the primary culture, but not in malignant cells, probably due to genetic determinism over activation of the latter. The enhancing of bacteria phagocytosis by macrophages after the exposure to mycobacterial antigens can be explained as the deception of immune system by mycobacteria, seeking to be captured by phagocytes for future survival and reproduction within the host. 


\section{Acknowledgments}

Authors thank Andrii Labyntsev, Mykhailo Guzyk and Kyrylo Pyrshev for technical support with flow cytometry. This work was supported by the State order for scientific and technical products.

\section{АНТИГЕНИ Mycobacterium tuberculosis МРТ63 ТА МРТ83 ПІДВИЩУЮТЬ ФАГОЦИТАРНУ АКТИВНІСТЬ ПЕРИТОНІАЛЬНИХ МАКРОФАГІВ МИШІ}

\section{А. А. Сіромолот ${ }^{l, 2}$, О. С. Олійник²,}

Д. В. Колибо ${ }^{2,1}$ С. В. Комісаренко

${ }^{1}$ ННЦ «Інститут біології», Київський національний університет імені Тараса Шевченка, Україна;

${ }^{2}$ Інститут біохімії ім. О. В. Палладіна НАН України, Київ; e-mail:saa0205@ukr.net

Макрофаги - найбільш описана та охарактеризована мішень та клітина-хазяїн для мікобактерій. I, як й іншим клітинам природного імунітету, макрофагам притаманний широкий спектр рецепторних молекул, що взаємодіють iз різноманітними патогенасоційованими молекулярними паттернами. Імунодомінантні антигени МРТ63 та МРТ83, що продукуються в значній кількості в штамах Mycobacterium bovis та Mycobacterium tuberculosis, можуть бути залучені до розвитку інфекції. Метою нашого дослідження був пошук деяких ефектів цих мікобактеріальних антигенів на клітини-мішені. Для цього було клоновано повнорозмірний антиген МРТ83 та МРТ63 в плазмідній ДНК $\mathrm{pET} 24 \mathrm{a}(+)$. Показано зростання фагоцитарної активності макрофагів із перитонеальної порожнини миші, але не макрофагоподібних клітин лінії J774, які були стимульовані rMPТ63 та rMPT83full протягом 24 год. Ефект цих антигенів можна розглядати як спосіб сприяння захоплення мікобактерій макрофагами для уникнення інших механізмів дії природного та набутого імунітету.

Ключов г с слова: Mycobacterium tuberculosis, Mycobacterium bovis, макрофаги, фагоцитоз, МРТ63, МРТ83.

\section{АНТИГЕНЫ Mycobacterium tuberculosis МРТ63 И МРТ83 ПОВЫШАЮТ ФАГОЦИТАРНУЮ АКТИВНОСТЬ ПЕРИТОНЕАЛЬНЫХ МАКРОФАГОВ МЫШИ}

\author{
А. А. Сиромолот ${ }^{1,2}$, Е. С. Олейник ${ }^{2}$, \\ Д. В. Колибо ${ }^{2,1}$, С. В. Комисаренко \\ 'УНЦ «Институт биологии», Киевский \\ национальный университет имени \\ Тараса Шевченко, Украина; \\ ${ }^{2}$ Институт биохимии им. А. В. Палладина \\ НАН Украины, Киев; \\ e-mail: saa0205@ukr.net
}

Макрофаги - наиболее описанная и охарактеризованная мишень и клетка-хозяин для микобактерий. И, как и другим клеткам естественного иммунитета, макрофагам присущ широкий спектр рецепторных молекул, взаимодействующих с разнообразными патогенассоциированными молекулярными паттернами. Иммунодоминантные антигены МРТ63 и МРТ83, которые продуцируются в значительном количестве в штаммах Mycobacterium bovis и Mycobacterium tuberculosis, могут быть задействованы в развитии инфекции. Целью нашего исследования был поиск некоторых эффектов этих микобактериальных антигенов на клетки-мишени. Для этого были клонированы полноразмерные антигены МРТ83 и МРТ63 в плазмидной ДНК рЕТ24а (+). Показан рост фагоцитарной активности макрофагов в перитонеальной полости мыши, но не макрофагоподобных клеток линии J774, которые стимулировались rMPT63 и rMPT83full на протяжении 24 ч. Эффект этих антигенов можно рассматривать как способ содействия захвату микобактерий макрофагами во избежание других механизмов действия естественного и приобретенного иммунитета.

Ключевы е слова: Mycobacterium tuberculosis, Mycobacterium bovis, макрофаги, фагоцитоз, МРТ63, МРТ83. 


\section{References}

1. Cole ST, Brosch R, Parkhill J, Garnier T, Churcher C, Harris D, Gordon SV, Eiglmeier K, Gas S, Barry CE 3rd, Tekaia F, Badcock K, Basham D, Brown D, Chillingworth T, Connor R, Davies R, Devlin K, Feltwell T, Gentles S, Hamlin N, Holroyd S, Hornsby T, Jagels K, Krogh A, McLean J, Moule S, Murphy L, Oliver K, Osborne J, Quail MA, Rajandream MA, Rogers J, Rutter S, Seeger K, Skelton J, Squares R, Squares S, Sulston JE, Taylor K, Whitehead S, Barrell BG. Deciphering the biology of Mycobacterium tuberculosis from the complete genome sequence. Nature. 1998; 393(6685): 537-544.

2. Palomino JC. Tuberculosis: from basic science to patient care. Palomino J.C., Leao S.C., Rittaco V. Brazil publishing, 2007. $686 \mathrm{p}$.

3. Russell DG. Who puts the tubercle in tuberculosis? Nat Rev Microbiol. 2007; 5(1): 3947.

4. Nagai S, Wiker HG, Harboe M, Kinomoto M. Isolation and partial characterization of major protein antigens in the culture fluid of Mycobacterium tuberculosis. Infect Immun. 1991; 59(1): 372-382.

5. Manca C, Lyashchenko K, Wiker HG, Usai D, Colangeli R, Gennaro ML. Molecular cloning, purification, and serological characterization of MPT63, a novel antigen secreted by Mycobacterium tuberculosis. Infect Immun. 1997; 65(1): 16-23.

6. Redchuk TA, Oliinyk OS, Kaberniuk AA, Burkalova DO, Romaniuk SI, Kolibo DV, Komisarenko SV. Cloning and expression of Mycobacterium bovis antigens MPB63 and MPB83 in Escherichia coli. Rep Nat Acad Sci Ukraine. 2007; 9: 161-166. (In Ukrainian).

7. Redchuk TA, Korotkevich NV, Kaberniuk AA, Oliinyk OS, Labyntsev AIu, Romaniuk SI, Kolibo DV, Busol VA, Komisarenko SV. Statistical analysis of the distribution of the antibody levels to Mycobacterium bovis antigenes for bovine tuberculosis diagnostics. Cytol Genet. 2010; 44(5): 280-285.

8. Goulding CW, Parseghian A, Sawaya MR, Cascio D, Apostol MI, Gennaro ML, Eisenberg D. Crystal structure of a major secreted protein of Mycobacterium tuberculosis-MPT63 at 1.5-A resolution. Protein Sci. 2002; 11(12): 2887-2893.
9. Camus JC, Pryor MJ, Médigue C, Cole ST. Re-annotation of the genome sequence of Mycobacterium tuberculosis H37Rv. Microbiology. 2002; 148(Pt 10): 2967-2973.

10. Muñoz S, Hernández-Pando R, Abraham SN, Enciso JA. Mast cell activation by Mycobacterium tuberculosis: mediator release and role of CD48. J Immunol. 2003; 170(11): 5590-5596.

11. Wiker HG. MPB70 and MPB83 - major antigens of Mycobacterium bovis. Scand J Immunol. 2009; 69(6): 492-499.

12. Chambers MA, Whelan AO, Spallek R, Singh M, Coddeville B, Guerardel Y, Elass E. Non-acylated Mycobacterium bovis glycoprotein MPB83 binds to TLR $1 / 2$ and stimulates production of matrix metalloproteinase 9. Biochem Biophys Res Commun. 2010; 400(3): 403-408.

13. Saraav I, Singh S, Sharma S. Outcome of Mycobacterium tuberculosis and Toll-like receptor interaction: immune response or immune evasion? Immunol Cell Biol. 2014; 92(9): 741-746.

14. Chen ST, Li JY, Zhang Y, Gao X, Cai H. Recombinant MPT83 derived from Mycobacterium tuberculosis induces cytokine production and upregulates the function of mouse macrophages through TLR2. J Immunol. 2012; 188(2): 668-677.

15. Gille C, Spring B, Tewes L, Poets CF, Orlikowsky T. A new method to quantify phagocy tosis and intracellular degradation using green fluorescent protein-labeled Escherichia coli: comparison of cord blood macrophages and peripheral blood macrophages of healthy adults. Cytometry A. 2006; 69(3): 152-154.

16. Steinkamp JA, Wilson JS, Saunders GC, Stewart CC. Phagocytosis: flow cytometric quantitation with fluorescent microspheres. Science. 1982; 215(4528): 64-66.

17. Stewart CC, Lehnert BE, Steinkamp JA. In vitro and in vivo measurement of phagocytosis by flow cytometry. Methods Enzymol. 1986; 132: 183-192.

18. Lugini L, Lozupone F, Matarrese P, Funaro C, Luciani F, Malorni W, Rivoltini L, Castelli C, Tinari A, Piris A, Parmiani G, Fais S. Potent phagocytic activity discriminates metastatic and primary human malignant melanomas: a key role of ezrin. Lab Invest. 2003; 83(11): 1555-1567.

Received 29.08.2016 